\title{
HYGIENE STATUS OF KITCHEN PRODUCTION AREAS OF HOSPITALITY FACILITIES
}

\author{
Eren Canbolat ${ }^{12}$ \\ Ayşe Nur Songür ${ }^{13}$ \\ Funda Pınar Çakıroğlu ${ }^{14}$
}

\begin{abstract}
Tourism sector is service sector. Food and beverage department is one of the important departments in the hospitality facilities. Service quality of this department attracts people to facilities apart from the purpose of the accommodation. Guests who stay in hospitality facilities may face food poisoning if hygiene and sanitation rules are not obey in food and beverage services. Therefore, cleaning in the kitchen is absolutely necessary. In this study, it is aimed to determine the hygienic conditions of the production areas of kitchens of hospitality facilities in Ankara. Method of study is seven different hospitality facilities in Ankara were visited, kitchen production areas were examined and hygiene evaluations were made by taking photographs. According to the findings it has been observed that in the kitchen production areas there were no suitable materials for hygiene in the floors and walls in five facilities and cracks, breachs, slits were found and height of the ceiling was low in four facilities. It has been determined that the work benches were made of suitable materials (steel-marble) in terms of usage but inappropriate in terms of cleanliness and order. It has been determined that the tools used for production was not clean, the work areas were not separated from each other except for three facilities, the garbage cans in the kitchen were not covered, the tops of the prepared food were kept open, the dirty-clean materials were kept together and the lighting and ventilation was not good in most of the kitchens. As a result the most of the kitchens surveyed bear the risk of cross-contamination. In the event of any food poisoning or dissatisfaction, facilities can also harm economically by losing reputation. Hygienic food production is an important issue that needs to be emphasized because of significance to both public health and economic prosperity in international trade. In food and beverage services should be available specialists for provide of hygienic qualities. Hygiene audit lists should be developed and continuously checked at the hospitality facilities.
\end{abstract}

Key words: hygiene, hospitality facility, food production

\section{INTRODUCTION}

The tourism industry is a service industry that requires intensive labor. The hospitality industry, which is one of the important areas of the industry, is examined in two separate divisions as accommodation and catering services. The hospitality industry's

12 Research Assistant, Department of Gastronomy and Culinary Arts, Faculty of Tourism, Ondokuz Mayıs University, Ada Street No:18 Bafra, 55430 Bafra/Samsun.

${ }^{13}$ Research Assistant, Department of Nutrition and Dietetics, Institute of Health Sciences, Ankara University, Plevne Street No:5 Altındağ, 06340 Altındağ/ Ankara.

14 Professor, Department of Nutrition and Dietetics, Faculty of Health Sciences, Ankara University, Plevne Street. No:5 Altındağ 06340,s Altındağ/ Ankara. 
income from the food and beverage division takes the second place after the income earned from accommodation services. For this reason, it is observed that the catering enterprises are getting more and more to apply hygiene to make a difference and protect the consumer health when the competitive conditions of the market are taken into consideration (Cömert et al., 2008).

Hygiene is defined as a science that applies as a synthesis of health-related information and documents for long-term protection, development, and maintenance of human health as individuals and society. In medicine, hygiene means health knowledge. At the same time, hygiene is compliance of the working environment, working system and works of catering companies to the health and cleaning regulations (Cömert and Özel, 2015). Hygiene which is indispensable for individuals in every aspect of their life plays a significant role in the success of the accommodation enterprises. This is because, as a result of the increasing level of education and awareness about the hygiene of the consumers, production of services offered to consumers as clean attentive, and aesthetic in accordance with the hygiene regulations has become among the qualifications expected from an enterprise. This has been a quite effective to regard the hygiene as a quality indicator. It is also known that it is necessary to give importance to the hygiene practices by enterprises to prevent the health and gain a trust of the people to whom these services are provided and the personnel (Tayar, 2013: 7).

Food, the basic substance of our lives, can harm our health in some cases. Bacteria, mold, viruses, parasites and chemical poisons mixed with food have adverse effects on health (Sökmen, 2003: 58). The most common causes of food poisoning in mass feeding systems are inadequate cooling $(46 \%)$, one or more days between preparation and consumption $(21 \%)$, infected personnel $(20 \%)$, applying wrong heating method (16\%), insufficient cooking (16\%), insufficient heating (16\%), use of contaminated ingredient $(11 \%)$, cross-contamination $(7 \%)$ use of bad food ingredients $(5 \%)$ and use of residual dishes (4\%). There are three factors to be aware of to prevent foodborne poisoning in catering organizations. These factors are nutrition hygiene, hygiene of the personnel, kitchen and utensil hygiene, respectively (Sezgin and Özkaya, 2015).

While food hygiene covers the hygiene regulations that should be followed during the purchase, storage, preparation and cooking of food and in the service of the food, hygiene of the personnel includes the whole hygiene of the hands and other body parts that may be possible to contact with the food. (Sevinç, 2010). Certain regulations to be considered for kitchen and utensil hygiene are given in Table 1 (Demirel, 2009). 
Table 1. Regulations to be obeyed for kitchen and utensil hygiene

\begin{tabular}{|l|l|}
\hline $\begin{array}{l}\text { Proper ventilation should be provided in } \\
\text { kitchen and dining areas. }\end{array}$ & $\begin{array}{l}\text { The storages should be always } \\
\text { checked in terms of temperature, } \\
\text { humidity, and harmful organisms like } \\
\text { pest, rodent etc. }\end{array}$ \\
\hline $\begin{array}{l}\text { During the ventilation, necessary measures } \\
\text { should be taken to ensure that insects will } \\
\text { not enter to these areas. }\end{array}$ & $\begin{array}{l}\text { The necessary care should be taken } \\
\text { to ensure that the first material stored } \\
\text { in the storage is the first material to } \\
\text { be used. }\end{array}$ \\
\hline $\begin{array}{l}\text { The necessary lighting should be provided } \\
\text { in the kitchen, especially for corners and } \\
\text { dark areas, to be able to see dead spots } \\
\text { clearly where insects can reproduce. }\end{array}$ & $\begin{array}{l}\text { Potentially dangerous foods should } \\
\text { be stored under refrigerator } \\
\text { conditions. }\end{array}$ \\
\hline $\begin{array}{l}\text { The kitchen floor should be constructed to } \\
\text { be easily cleanable, durable, non-slip, light, } \\
\text { smooth, nonabsorbent, and free of cuts, } \\
\text { cracks, and voids at joints. Kitchen floor } \\
\text { should be washed at least once a day with } \\
\text { detergent containing disinfectant. }\end{array}$ & $\begin{array}{l}\text { The garbage cans that can be opened } \\
\text { with a pedal and are closed should be } \\
\text { placed in places away from the food } \\
\text { areas in the kitchen, nylon bags } \\
\text { should be placed inside them and } \\
\text { they should be washed with } \\
\text { disinfectant detergent after each } \\
\text { discharge. }\end{array}$ \\
\hline $\begin{array}{l}\text { The necessary care should be taken to } \\
\text { ensure that the walls are washed as they } \\
\text { become soiled and that the ceilings are not } \\
\text { dirty and swollen and have a contaminating } \\
\text { condition. }\end{array}$ & $\begin{array}{l}\text { The lists indicating the use, cleaning } \\
\text { and care of every tool used in the } \\
\text { kitchen should be placed in the } \\
\text { appropriate places. }\end{array}$ \\
\hline $\begin{array}{l}\text { The personnel should be provided with a } \\
\text { room where they change their clothes } \\
\text { comfortably, adequate wardrobes, and a } \\
\text { shower. }\end{array}$ & $\begin{array}{l}\text { Microbiological controls of the } \\
\text { drinking water should be conducted } \\
\text { at certain intervals. }\end{array}$ \\
\hline
\end{tabular}

It is known that quality and health are an inseparable whole in the catering enterprises. Improper preparation, processing, and sanitation of food and non-obeying personal hygiene regulations can lead to food-borne illnesses and even deaths. Besides, this can result in economic losses due to loss of reputation for an enterprise. For this reason, hygienic quality of foods should be high. The basic conditions for achieving this are to comply with hygiene regulations, identify risky points in terms of hygiene and take necessary precautions. Considering this information, this study was conducted to assess the hygiene conditions of the kitchen production areas of accommodation enterprises. 


\section{METHODOLOGY}

This study having observational and descriptive design was conducted with the accommodation enterprises located in Ankara city center. According to data of the Ministry of Culture and Tourism of the Republic of Turkey in 2016, there are a total of 201 accommodation enterprises in Ankara province;

26 with tourism investment license and 175 with tourism operation license (http://yigm.kulturturizm.gov.tr/TR,9860/turizm-belgeli-tesisler.html).

For this reason, the research population is composed of 201 accommodation enterprises. The following formula was utilized to choose to sample volume. $90 \%$ confidence coefficient and $20 \%$ error margin were taken into consideration in that formula. The rule of thumb applied in this type of sampling is $(p)=(q)=0.5$. In this case, a constant sampling error results in the largest possible sample volume (Malhotra, 1993).

$\mathrm{n}=\frac{\mathrm{N} \cdot \mathrm{t}^{2} \cdot \mathrm{p} \cdot \mathrm{q}}{\mathrm{d}^{2} \cdot(\mathrm{N}-1)+\mathrm{t}^{2} \cdot \mathrm{p} \cdot \mathrm{q}}$

$\mathrm{N}$ : Study population

$\mathrm{n}$ : Sample volume

$\mathrm{t}$ : confidence coefficient

d: Sampling error

The sample size was calculated as 16 upon the application of the formula. Random sampling method was utilized in the selection of the sample, but only 7 accommodation enterprises agreed to participate in the study. Three of the accommodation enterprises that accepted to participate in the study are 4-star hotels and 4 of them are 5-star hotels. The kitchens of the visited hotels were examined, and hygiene assessments were made by taking photographs in the scope of this study.

\section{RESULTS AND DISCUSSION}

Five of the participating hotels were found to use materials unsuitable for hygiene in the construction of kitchen floors and walls. In addition, fractures and cracks were detected on the floors of kitchens of four hotels and their ceiling heights were low (Figure 1). The material to be selected for kitchen floors and walls is important for the health and motivation of the personnel during the workflow. The material to be selected for the floors of the kitchen should definitely be selected from the non-slip material. A slippery kitchen floor can lead to all kinds of work accidents (Special and Generous, 2015). In this study, it was determined that the vast majority of the hotels do not comply with the regulations in terms of kitchen floor, walls and ceilings. 


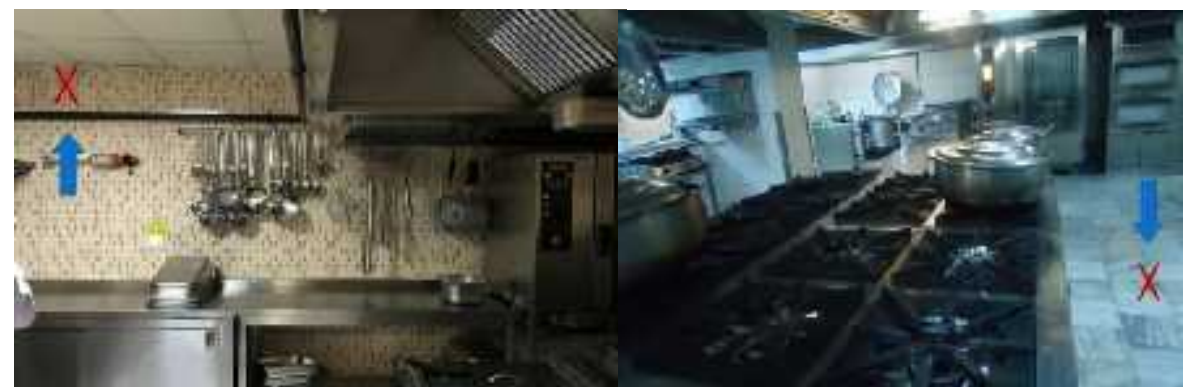

Fig. 1. Kitchen floor, walls and ceiling

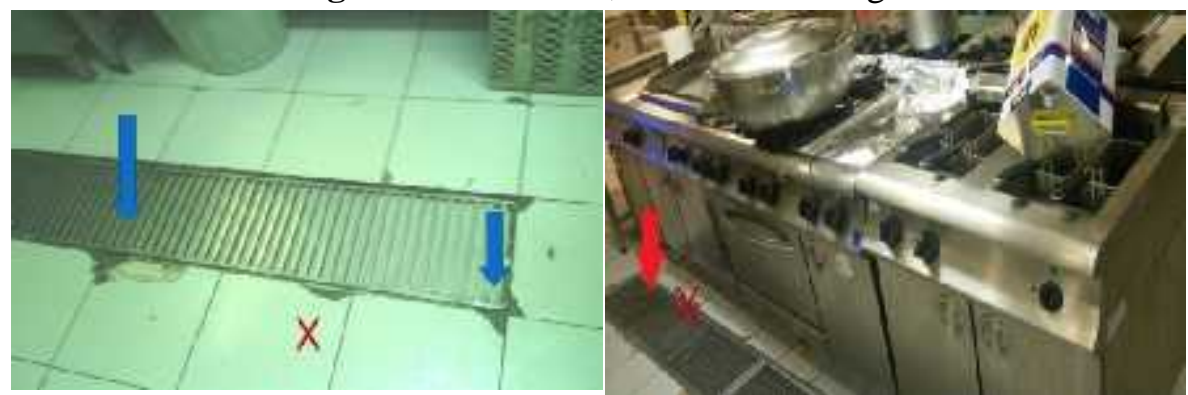

Fig. 1. (Continuation) Kitchen floor, walls and ceiling

It was found that the working benches of the three of hotel kitchens' preparation section are made from suitable materials (steel marble) in terms of usability use, but are not suitable for hygiene regulations in terms of cleanliness and layout (Figure 2). Failure to comply with hygiene rules on workbenches can lead to foodborne illnesses, poisonings, and even deaths. Likewise, hygienically inappropriate conditions were detected in cooking sections.

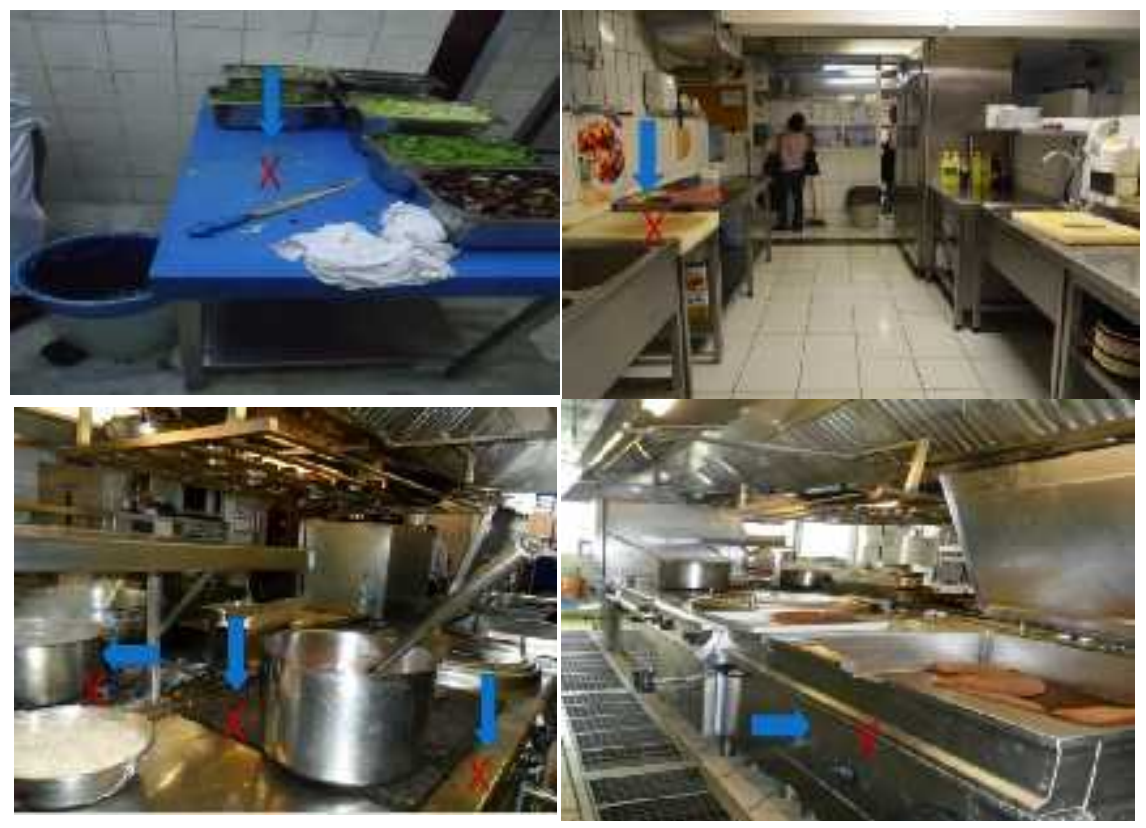

Fig. 2. Preparation and cooking areas 
Garbage cans which are the closed type, cylindrically shaped, of suitable size, made of stainless steel, and can be opened with a lid pedal if possible should be placed in appropriate stations within the kitchen (Ersin and Beyhan, 2001). In this study, it was determined that garbage cans in the kitchen were open in two of the participating hotels (Figure 3). It is known that this condition is not appropriate in terms of hygiene regulations and may cause dangerous consequences for health.

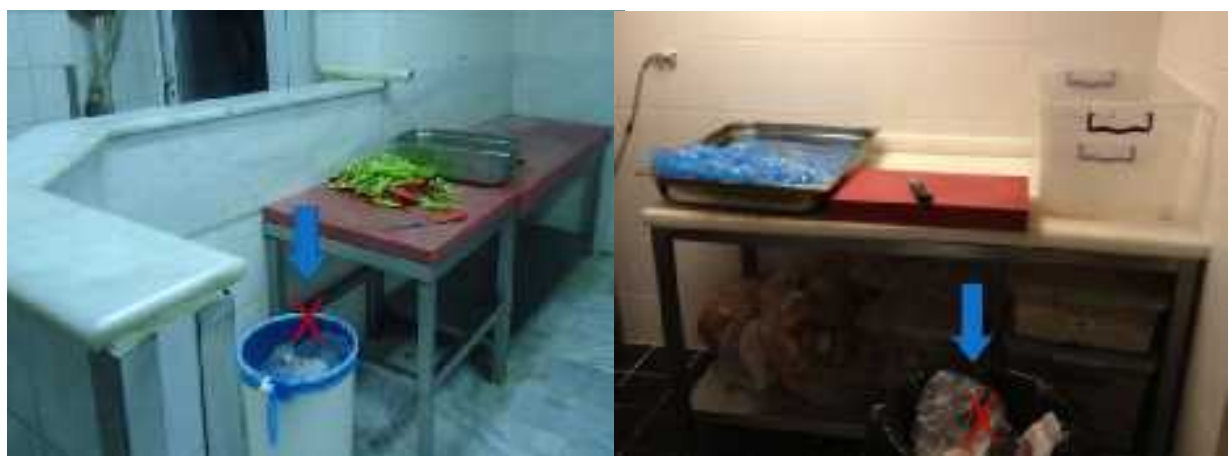

Fig. 3. Garbage cans

The food left in the hotel kitchen is presented in Figure 4. Leaving the food as not being covered is thought to cause multiplication of microorganisms on the food and increase the risk of food poisoning. In addition, cooked foods should be served within 2-4 hours without falling their internal temperature below $60^{\circ} \mathrm{C}$ and stored at suitable storage conditions with reduced temperatures.

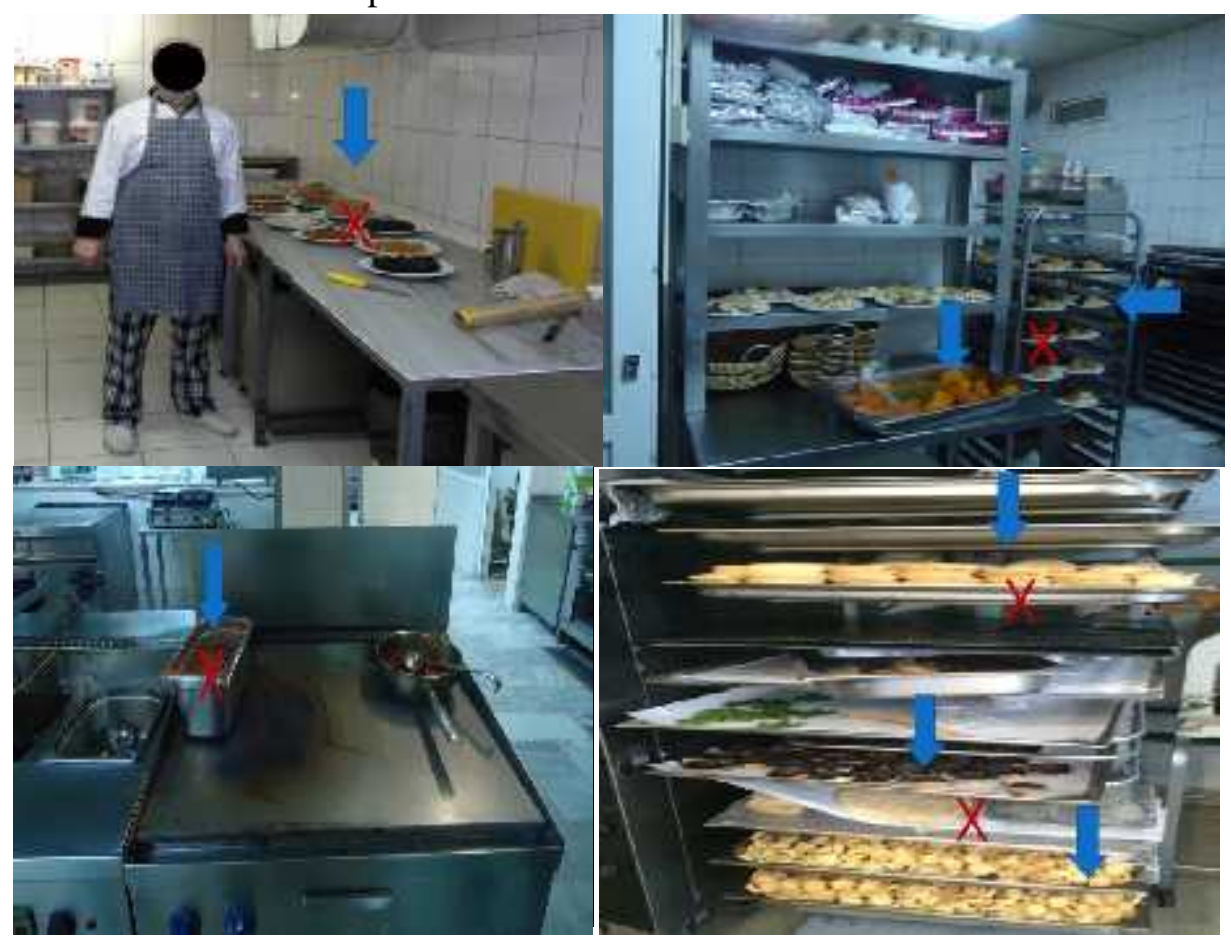

Fig. 4. Cooked foods left open 
In the study, it was determined that most of the visited hotels have inadequate lighting and ventilation conditions. Inadequate lighting results in difficulty in the working conditions of the personnel, a decrease in work efficiency, and work accidents. Inadequate ventilation affects health and working conditions of the personnel adversely. Finally, it was determined that working sections in three of the examined hotel kitchens are not separated from each other. It is indicated that such a case will break down the workflow in the kitchen and lead to inappropriate food production by increasing the risk of cross-contamination. Some of the adverse situations described are shown in Figure 5.

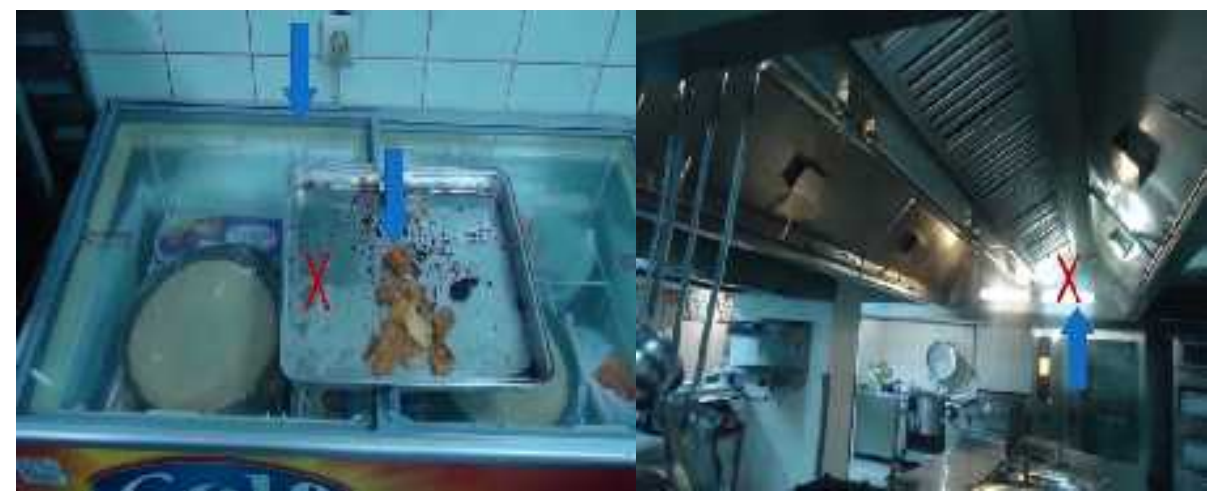

Fig. 5. Some images of other adverse conditions

\section{CONCLUSION}

Mass Feeding is defined as the feeding of people by non-domestic service providers with foods or dishes and these service providers are called "Catering Organizations" (Hayter 2002). Hygiene is a vital pre-requisite for accommodation enterprises that provide mass feeding services. Success in this sector can be achieved by offering hygienic, safe, clean, high quality and healthy foods and beverages to consumers (Sökmen, 2008). High-cost consequences such as food poisoning, loss of customer and prestige, forbidden practices/punishment, depression in personnel, lack of motivation, exposure through press organs may be resulted in since the hygiene regulations are not complied with in the accommodation enterprises (Demirel, 2009).

This study was carried out to assess hygienic aspects of production areas of the kitchens in accommodation enterprises. The study universe was determined as the accommodation enterprises in Ankara and it was ascertained that 16 accommodation enterprises should be included in the study with the formula applied to the sample to represent the universe. However, the study was conducted with 7 accommodation enterprises since the majority of enterprise owners did not want to show their production areas of the kitchens. For this reason, the sample represented $43.75 \%$ of the universe and this constitutes a limitation for the study. As a result of the study, it was determined that the majority of the visited hotels did not adequately apply the 
regulations to be obeyed for kitchen and utensil hygiene. The study results and recommendations are as follows:

- The most of the kitchens surveyed bear the risk of cross-contamination.

- In the event of any food poisoning or dissatisfaction, facilities can also harm economically by losing reputation.

- Hygienic food production is an important issue that needs to be emphasized because of significance to both public health and economic prosperity in international trade.

- In food and beverage services should be available specialists for provide of hygienic qualities.

- Hygiene audit lists should be developed and continuously checked at the hospitality facilities.

- Implementation of a Hazard Analyses Critical Control Points (HACCP) system, a globally accepted method of food safety and security, in accommodation enterprises will ensure hygiene and nutritional problems are avoided.

\section{REFERENCES}

1. Cömert, M., Durlu Özkaya, F. Ve Şanlıer, N. (2008). Otellerde Gıda Güvenliği. Türkiye 10. G1da Kongresi, 21-23 May 2008, Erzurum, Türkiye

2. Cömert, M. ve Özel, K. (2015). Otel şletmelerinde Hijyen ve Sanitasyon Kurallarının Mutfak Personeli Tarafindan Bilinirlik Ve Uygulanma Düzeyi. Akademik Sosyal Araştırmalar Dergisi, 3, 16, 310-322

3. Demirel, S. (2009). Hazır Yemek Üretimi Yapan şletmelerde Çalışanların Hijyen Bilgi Düzeylerinin Belirlenmesi. (Yüksek Lisans Tezi). Namık Kemal Üniversitesi Fen Bilimleri Enstitüsü, Tekirdağ.

4. Ersin, M. ve Beyhan, Y. (2001). Toplu Beslenme Sistemlerinde Hijyen Sanitasyonu Să̆lama Önerileri. Mesleki Să̆llk ve Güvenlik Dergisi, 2(8), 19 26.

5. Hayter, R. (2002). Food Preparation and Cooking. Hotel \& Catering Company.

6. Malhaotra, N.K (1993). Marketing Research. McGrow Hill, International Edition.

7. Özel, K. ve Cömert, M. (2015). Otel şletmeleri Mutfak Çalışanlarının Mutfak Planlamast le lgili Bilgi Düzeylerinin Belirlenmesi. Journal of Tourism and Gastronomy Studies, 3(2), 48-55. 
8. Sevinç, Y. (2010). Toplu Yemek Sektöründe Yaşanan Problemler ve Çözüm Yolları. (Yüksek Lisans Tezi). Namık Kemal Üniversitesi Fen Bilimleri Enstitüsü, Tekirda $\breve{g}$.

9. Sezgin, A.C. ve Özkaya, F.D. (2014). Toplu beslenme sistemlerine genel bir bakıs. Akademik Gıda, 12(1), 124-128.

10. Sökmen, A (2003). Ağırlama Endüstrisinde Yiyecek Ve çecek Yönetimi. Ankara: Detay Yayıncllk.

11. Tayar, M. (2013). Hijyen ve Sanitasyon. (3.Baskı). Eskiş̧ehir: Anadolu Üniversitesi Web Ofset.

12. http://yigm.kulturturizm.gov.tr/TR,9860/turizm-belgeli-tesisler.html 